\title{
Modulation of Post-Prandial Insulin Release by Ingested Opiate-Like Substances in Dogs
}

\author{
V.Schusdziarra, A. Holland, R. Schick, A. de la Fuente, M. Klier, V. Maier, V. Brantl ${ }^{1}$ and E. F.Pfeiffer \\ Department of Internal Medicine I, University of Ulm, and 'Department of Neuropharmacology, \\ Max Planck Institute of Psychiatry, Munich, FRG
}

\begin{abstract}
Summary. We have previously demonstrated that opiate-like substances in food protein (exorphins), contained in the peptic digest of gluten, stimulate insulin and glucagon release in dogs and that this effect is inhibited by the opiate antagonist naloxone. The present study was designed to evaluate the possible rôle of ingested opiate-like substances in the modulation of post-prandial insulin release. Similarly, the addition of synthetic $\beta$-casomorphins, which are the opioid-active material of bovine casein peptone, elicit a stimulation of post-prandial insulin release during a liver extract-sucrose test meal. The addition of met-enkephalin to a liver extract-sucrose test meal also augmented the post-prandial insulin response. Both stimulatory effects were reversed by oral naloxone, as was the post-
\end{abstract}

prandial increase of insulin following ingestion of bovine casein peptone (casopeptone). The post-prandial insulin response to digested and undigested liver extract was not affected by naloxone, suggesting that the foregoing effects are likely to be specific to opiate-like materials contained in foodstuff (exorphins). In view of previous findings, the present data are compatible with a role of opiate-like substances contained in ingested nutrients in the regulation of post-prandial insulin secretion.

Key words: $\beta$-Casomorphin, enkephalin, naloxone, insulin release, exorphins, opiates, dog.
Opiate-like substances such as $\beta$-endorphin, and enkephalin, have been shown to be present in the gastrointestinal tract and pancreas [1-6], and have widespread potent effects on gastric, intestinal and pancreatic exoand endocrine functions when administered intravenously [7-18]. With the discovery of substances with opiate-like activity in foodstuff (exorphins), such as wheat gluten, bovine and human milk and bovine casein peptone [19-22], it is important to establish whether oral ingestion of such compounds might regulate post-prandial gastrointestinal and pancreatic endocrine functions. Recently we have shown that intragastric instillation of exorphins contained in the peptic digest of gluten stimulate insulin and glucagon release in dogs [23], and the demonstration of naloxone-induced inhibition of these effects indicates that opiate-receptors are activated in the gastrointestinal tract and/or pancreas. The present study was designed to extend the examination of post-prandial insulin release in response to test meals that contain opiate-like substances. To demonstrate the involvement of opiate receptors, naloxone, a specific opiate receptor antagonist [24], was added to the test meals.

\section{Materials and Methods}

\begin{abstract}
Animals
The studies were performed in a total number of 12 conscious normal dogs (body weight $25-35 \mathrm{~kg}$ ). After an overnight fast the dogs received an intragastric test meal according to the following protocols. All experiments were carried out in randomized order and each dog served as its own control: (1) In eight dogs, $25 \mathrm{~g}$ of bovine casein peptone (casopeptone, C/TLG 16300, Serva Feinbiochemica, Heidelberg, FRG), together with saline ( $5 \mathrm{ml}, 0.15 \mathrm{~mol} / \mathrm{l})$ or naloxone $(8 \mathrm{mg}$, Endo Laboratories, Garden City, USA) were given orally. This test meal was chosen because it has been shown previously to contain approximately $25 \mathrm{mg}$ of opioid-active $\beta$-casomorphins [20, 21]. (2) In a second group of eight dogs, a mixture of synthetic $\beta$-casomorphins (3 mg $\beta$-casomorphin-7, $3 \mathrm{mg} \beta$-casomorphin-5, $4 \mathrm{mg} \beta$-casomorphin- 4 and $4 \mathrm{mg} \beta$-casomorphin-4-amide) (Peninsula, La Jolla, USA and Bachem, Bubendorf, Switzerland) was added to a test meal consisting of $50 \mathrm{~g}$ undigested liver extract (Reheis Chemicals, Chicago) and $25 \mathrm{~g}$ sucrose. For comparison the same meal contained either saline or the mixture of casomorphins $+10 \mathrm{mg}$ naloxone. (3) In eight dogs, met-enkephalin (10 mg) (Serva, Heidelberg, FRG) was added to a test meal consisting of $50 \mathrm{~g}$ undigested liver extract and $50 \mathrm{~g}$ sucrose. The same meal was also given containing either saline or $10 \mathrm{mg}$ metenkephalin $+10 \mathrm{mg}$ naloxone. (4) The foregoing and previously reported effects may be due to the fact that the peptic digest of protein meals contains more amino acids and/or oligopeptides than the undigested form, which could increase post-prandial insulin release per se.
\end{abstract}




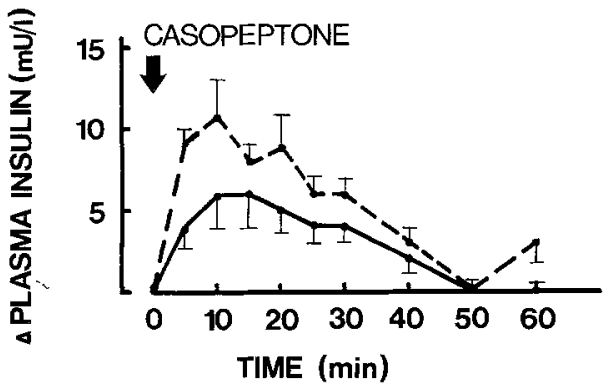

Fig.1. Effect of the intragastric administration of naloxone $(8 \mathrm{mg})$ (-) or saline (-.- ) together with the casopeptone test meal ( $25 \mathrm{~g}$ in $300 \mathrm{ml}$ water) on the increase in post-prandial peripheral vein plasma insulin levels ( \pm SEM) above the mean of the three baseline values in eight conscious dogs

Therefore, another test meal with presently unknown content of opiate-like material - bovine liver extract - was employed in the present study. Twenty-five g undigested liver extract (eight dogs) or $25 \mathrm{~g}$ digested liver extract (six dogs) were administered intragastrically with oral naloxone or saline, respectively. The peptic digest of liver extract was prepared as described by Zioudrou et al. [19] and after the 2-h incubation period the reaction was stopped by neutralization and subsequent lyophilization.

All test meals were dissolved in $300 \mathrm{ml}$ water just before the instillation via a gastric tube. Blood samples were drawn from a crural vein before and at $5 \mathrm{~min}$ intervals for $30 \mathrm{~min}$ and at $10 \mathrm{~min}$ intervals until $60 \mathrm{~min}$ after the instillation of the test meal, and blood was collected into chilled tubes containing $500 \mathrm{KIU}$ Trasylol and $6 \mathrm{mg}$ EDTA. All samples were centrifuged at $2000 \mathrm{rev} / \mathrm{min}$ at $4{ }^{\circ} \mathrm{C}$ for $20 \mathrm{~min}$ and the separated plasma was frozen until the time of assay. Plasma insulin levels were determined by radioimmunoassay as described previously [25] and glucose was measured by the glucose-oxidase method using the Technicon autoanalyzer. For statistical comparisons Student's ttest for paired data was employed and $p$ values of 0.05 or less were considered significant. Incremental data were calculated as the sum of the values at each time point above the mean of the three baseline samples.

\section{Results}

\section{Response to Casopeptone}

Plasma insulin levels rose in response to casopeptone and saline from a mean baseline of $5 \pm 0.5$ to $16 \pm$ $4 \mathrm{mU} / 1$ at $10 \mathrm{~min}$. The addition of naloxone to the casopeptone meal elicited a maximal increase by only $6 \mathrm{mU} / 1$ from similar baseline levels (Fig.1). The incremental insulin level during the first 20 min was $23 \pm$ $3 \mathrm{mU} / 1$ after casopeptone and naloxone, significantly below the level of $49 \pm 3 \mathrm{mU} / 1$ in response to saline and casopeptone $(p<0.01)$. Plasma glucose levels did not rise during the casopeptone meal and were not affected by oral naloxone.

\section{Effect of Oral $\beta$-Casomorphins Upon the Insulin Response to a Liver Extract-Sucrose Test Meal}

In the saline control animals plasma insulin levels rose from a mean baseline of $10 \pm 2$ to a maximum of $37 \pm$ $6 \mathrm{mU} / \mathrm{l}$ at $15 \mathrm{~min}$, returning thereafter to baseline levels

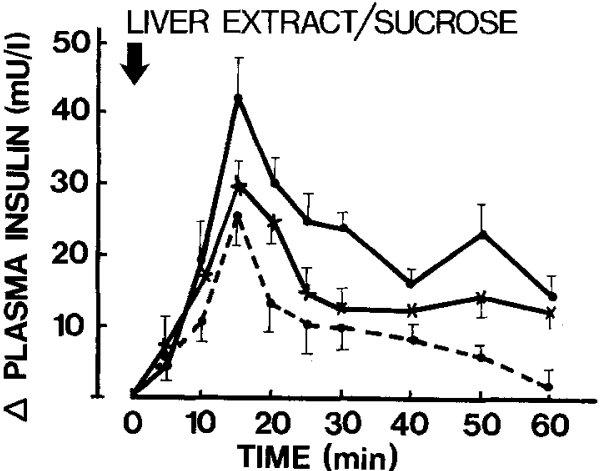

Fig. 2. Effect of the intragastric administration of a mixture of synthetic $\beta$-casomorphins (-), $\beta$-casomorphins + naloxone $(10 \mathrm{mg})$ $(x-x)$, or saline $(---)$ ) together with a liver extract-sucrose test meal $(50 \mathrm{~g}$ liver extract and $25 \mathrm{~g}$ sucrose in $300 \mathrm{ml}$ water) on the increase in post-prandial, peripheral vein plasma insulin levels ( \pm SEM) above the mean of the three baseline values in eight conscious dogs

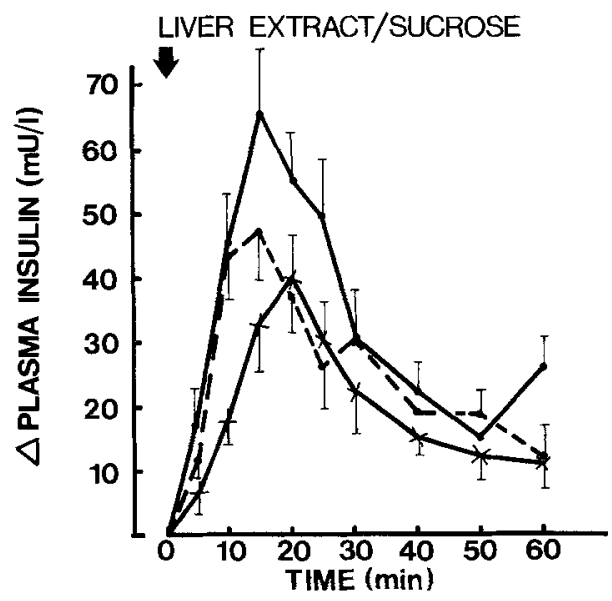

Fig.3. Effect of the intragastric administration of met-enkephalin $(10 \mathrm{mg})(-)$, met-enkephalin $(10 \mathrm{mg})+$ naloxone $(10 \mathrm{mg})$ $(x-x)$, or saline $(-\ldots)$ together with a liver extract-sucrose test meal ( $50 \mathrm{~g}$ liver extract and $50 \mathrm{~g}$ sucrose in $300 \mathrm{ml}$ water) on the increase in post-prandial peripheral vein plasma insulin levels $( \pm$ SEM) above the mean of the three baseline values in eight conscious dogs

(Fig. 2). The addition of $\beta$-casomorphins elicited a stimulation of insulin release from a mean baseline of $8 \pm 1$ to $50 \pm 4 \mathrm{mU} / \mathrm{l}$; insulin levels remained above those of the controls for the entire experimental period of $60 \mathrm{~min}$. The incremental insulin level during the $60 \mathrm{~min}$ was $222 \pm 40 \mathrm{mU} / 1$, significantly above the $104 \pm$ $28 \mathrm{mU} / 1$ of the controls $(p<0.025)$. The addition of naloxone to the test meal attenuated this stimulatory effect of $\beta$-casomorphins ( $159 \pm 25 \mathrm{mU} / 1 ; p<0.05$ and not significantly greater compared with the controls). The rise of peripheral vein plasma glucose levels by $0.5 \mathrm{mmol} / \mathrm{l}$ in the controls was not altered by the addition of $\beta$-casomorphins. 


\section{Effect of Oral Met-Enkephalin upon the Insulin Response to a Liver Extract-Sucrose Test Meal}

In response to the liver extract-sucrose test meal, plasma insulin rose from a mean baseline of $6 \pm 1.5$ to a maximum of $53 \pm 8 \mathrm{mU} / 1$ at $15 \mathrm{~min}$, returning thereafter to baseline levels (Fig. 3 ). The addition of $10 \mathrm{mg}$ met-enkephalin elicited a rise from a baseline of $7 \pm 1$ to a maximum of $72 \pm 12 \mathrm{mU} / 1$ at $15 \mathrm{~min}$ and remained above the levels of the saline-containing test meal for the first $30 \mathrm{~min}$. The incremental insulin level during the first $30 \mathrm{~min}$ was $265 \pm 40 \mathrm{mU} / 1$, significantly greater than the $185 \pm 25 \mathrm{mU} / 1$ in the controls $(p<0.05)$. The additional intragastric instillation of $10 \mathrm{mg}$ naloxone reduced the stimulatory effect of met-enkephalin upon post-prandial insulin levels $(170 \pm 25 \mathrm{mU} / 1, p<0.02)$.

Peripheral vein plasma glucose levels rose by $0.66 \mathrm{mmol} / 1$ above the mean baseline of $4.68 \mathrm{mmol} / 1$ and this response was not changed by the addition of met-enkephalin and naloxone.

\section{Response to Digested and Undigested Liver Extract}

In response to digested liver extract insulin rose from a mean baseline of $5 \pm 1$ to $14 \pm 4 \mathrm{mU} / 1$ at $15 \mathrm{~min}$ decreasing thereafter towards baseline levels. This response was not affected by oral naloxone. The incremental insulin level in response to digested liver extract and saline was $34 \pm 3.5 \mathrm{mU} / 1$ - not significantly different from the $36 \pm 4.7 \mathrm{mU} / 1$ after naloxone.

After the meal of undigested liver extract, insulin rose from the mean baseline of $9 \pm 1.5$ to $31 \pm 6 \mathrm{mU} / 1$ at $20 \mathrm{~min}$. The response was not significantly changed by naloxone. The incremental insulin level was $89 \pm$ $6 \mathrm{mU} / 1$ in response to undigested liver extract and saline, and $83 \pm 5 \mathrm{mU} / 1$ after the addition of naloxone.

In contrast to the greater insulin response to digested gluten compared with the undigested gluten meal [23], the incremental insulin level in response to undigested liver extract and saline $(89 \pm 6 \mathrm{mU} / 1)$ was significantly greater than that to digested liver extract and saline (34 $\pm 3.5 \mathrm{mU} / 1, p<0.005)$, suggesting that peptic digestion per se does not raise post-prandial insulin secretion.

Peripheral vein plasma glucose levels did not rise in response to digested or undigested liver extract and were not affected by naloxone.

\section{Discussion}

The present study demonstrates that test meals which contain opioid-active materials influence post-prandial insulin secretion in accordance with previously reported results [23]. Casopeptone, containing the opiate-like substances casomorphins $[20,21]$, stimulated insulin release and this effect was reduced by opiate receptor blockade. A similar effect can be obtained by the ad- ministration of synthetic $\beta$-casomorphins together with a carbohydrate-protein test meal. Further support for a modulatory role of ingested opiate-like substances is derived from the experiments with the opiate agonist met-enkephalin, which stimulates insulin release specifically via opiate receptors. These and previously reported effects [23] are not the consequence of peptic digestion of any protein test meal, as shown by the results obtained with liver extract, and probably reflect more specific, opiate-receptor mediated effects, which are induced by certain test meals only.

The mechanism of action of exorphins on islet cell function is unknown. From the present data it cannot be decided whether exorphins affect opiate-receptors within the gastrointestinal tract, thereby influencing the hormonal and/or neural signal between gut and islets of Langerhans, or whether the effect is due to absorbed exorphins exerting their effect at the level of the B cell, as shown for two other opiates [7,9]. The data are consistent with the hypothesis that not only the intravenous administration of opiates but also the oral ingestion of opiate-like substances contained in certain nutrients (exorphins) can influence the regulation of post-prandial insulin release. Whether these effects of exorphins are of any importance in the postulated role of opiates in nutrient intake $[26,27]$ remains to be established in further studies.

Acknowledgements. The authors want to thank W. Friedrich for expert technical assistance. The work was supported by Deutsche Forschungsgemeinschaft SFB 87 G6.

\section{References}

1. Polak JM, Bloom SR, Sullivan SN, Facer P, Pearse AGE (1977) Enkephalin-like immunoreactivity in the human gastrointestinal tract. Lancet 1: 972-974

2. Uddman R, Alumets J, Håkanson R, Sundler F, Walles B (1980) Peptidergic (enkephalin) innervation of the mammalian oesophagus. Gastroenterology 78: 732-737

3. Forssman WG, Helmstaedter V, Feurle G (1977) Relationship of enkephalin and endorphin immunoreactivity with D-cells and Gcells of the stomach. Hepatogastroenterology 24: 488-491

4. Bruni JF, Watkins WB, Yen SSC (1979) $\beta$-endorphin in the human pancreas. J Clin Endocrinol Metab 49:649-651

5. Grube D, Voight KH, Weber E (1978) Pancreatic glucagon cells contain endorphin-like immunoreactivity. Histochemistry 59: 75-79

6. Larsson L (1979) Innervation of the pancreas by substance P, enkephalin, vasoactive intestinal polypeptide and gastrin/CCK immunoreactive nerves. J Histochem Cytochem 27: 1283-1284

7. Ipp E, Dobbs R, Unger RH (1978) Morphine and $\beta$-endorphin influence the secretion of the endocrine pancreas. Nature 276: 190-191

8. Ipp E, Schusdziarra V, Harris V, Unger RH (1980) Morphine-induced hyperglycemia: role of insulin and glucagon. Endocrinology 107: 461-463

9. Green IC, Perrin D, Pedley KC, Leslie RDG, Pyke DA (1980) Effect of enkephalin and morphine on insulin secretion from isolated rat islets. Diabetologia 19:158-161

10. Kanter RA, Ensinck JW, Fujimoto WY (1980) Disparate effects of enkephalin and morphine upon insulin and glucagon secretion on islet cell cultures. Diabetes 29: 84-86 
11. Kachur JF, Miller RJ, Field M (1980) Control of guinea pig intestinal electrolyte secretion by an opiate receptor. Proc Natl Acad Sci 77: $2753-2756$

12. Chey WY, Coy DH, Konturek SJ, Schally AV, Tasler J (1980) Enkephalin inhibits the release and action of secretin on pancreatic secretion in the dog. J Physiol 298: 429-436

13. Stubbs WA, Jones A, Edwards GRW, Delitala G, Jeffcoate WJ, Ratter SJ, Besser GM, Bloom SR, Alberti KGMM (1978) Hormonal and metabolic responses to an enkephalin analogue in normal man. Lancet 2: 1225-1227

14. Riegel F (1900) Über den Einfluß des Morphiums auf die Magensaftsekretion. Z Klin Med 40:347-350

15. Magee DF (1975) Action of morphine sulphate on stimulated gastric secretion in dogs. Gastroenterology 68: 1340-1343

16. Morley JE, Branetsky NG, Wingert TD, Carlson HE, Hershman JE, Melmed S, Levin SR, Jamison KR, Weitzman R, Chang RJ, Varner AA (1980) Endocrine effects of naloxone-induced opiate receptor blockade. J Clin Endocrinol Metab 50:251-257

17. Reid RL, Yen SSC (1981) $\beta$-endorphin stimulates the secretion of insulin and glucagon in humans. J Clin Endocrinol Metab 52: 592-594

18. Feldman M, Walsh JH, Taylor IL (1980) Effect of naloxone and morphine on gastric acid secretion and on serum gastrin and pancreatic polypeptide concentrations in humans. Gastroenterology 79: 294-298

19. Zioudrou C, Streaty RA, Klee WA (1979) Opioid peptides derived from food proteins. J Biol Chem 254: 2446-2449

20. Brantl V, Teschemacher H, Henschen A, Lottspeich F (1979) Novel opioid peptides derived from casein ( $\beta$-casomorphin). Hoppe Seylers Z Physiol Chem 360: 1211-1216

21. Brantl V, Teschemacher H (1979) A material with opioid activity in bovine milk and milk products. Naunyn Schmiedebergs Arch Pharmacol 303: 301-304
22. Hazum E, Sabatka JJ, Chang K, Brent DA, Findlay JWA, Cuatrecasas $P$ (1981) Morphine in cow and human milk: could dietary morphine constitute a ligand for specific morphine receptors? Science 213: 1010-1012

23. Schusdziarra V, Henrichs I, Holland A, Klier M, Pfeiffer EF (1981) Evidence for an effect of exorphins on plasma insulin and glucagon levels in dogs. Diabetes 30:362-364

24. Blumberg H, Dayton HB (1972) Naloxone and related compounds. In: Kosterlitz HW, Collier HOJ, Villareal JE (eds) Agonist and antagonist actions of narcotic analgesic drugs. Macmillan Press, London, pp 110-119

25. Herbert V, Lau LS, Gottlieb CW, Bleicher SF (1965) Coated charcoal immunoassay of insulin. J Clin Endocrinol Metab 25: $1375-1384$

26. Margules DL, Moisset B, Lewis MJ, Shibuya H, Pert CB (1978) $\beta$ endorphin is associated with over-eating in genetically obese mice (ob/ob) and rats $(\mathrm{fa} / \mathrm{fa})$. Science 202: 988-991

27. Brands B, Thornhill JA, Hirst M, Gowdey CW (1979) Suppression of food intake and body weight gain by naloxone in rats. Life Sciences 24: 1773-1778

Received: 11 December 1981

and in revised form: 19 August 1982

Dr. V.Schusdziarra

Zentrum für Innere Medizin

University of Ulm

Steinhoevelstraße 9

D-7900 Ulm/Donau

FRG 